\title{
Inhibition of Maternal-to-Fetal Transfer of IgG Antibodies by FcRn Blockade in a Mouse Model of Arthrogryposis Multiplex Congenita
}

Ester Coutinho, MD, DPhil, Leslie Jacobson, DPhil, Anthony Shock, PhD, Bryan Smith, PhD, Anthony Vernon, PhD,* and Angela Vincent, MD, FRCPath*

Neurol Neuroimmunol Neuroinflamm 2021;8:e1011. doi:10.1212/NXI.0000000000001011

\section{Abstract}

\section{Objective}

To determine whether blocking the neonatal $\mathrm{Fc}_{\mathrm{c}}$ receptor $(\mathrm{FcRn})$ during gestation with an anti$\mathrm{FcRn}$ monoclonal antibody ( $\mathrm{mAb}$ ) reduces transfer of pathogenic maternal antibodies in utero and decreases the likelihood of maternal antibody-mediated neonatal disease in the offspring.

\section{Methods}

Using a previously established maternal-to-fetal transfer mouse model of arthrogryposis multiplex congenita (AMC), we assessed the effect of 4470, an anti-FcRn mAb, on the transfer of total human immunoglobulin $\mathrm{G}(\mathrm{IgG})$ and specific acetylcholine receptor (AChR)-antibodies from mother to fetus, as well as its effect on the prevention of neurodevelopmental abnormalities in the offspring.

\section{Results}

Offspring of pregnant dams treated with 4470 during gestation showed a substantial reduction in total human IgG and AChR antibody levels compared with those treated with the isotype $\mathrm{mAb}$ control. Treatment with 4470 was also associated with a significant reduction in AMCIgG-induced deformities (limb or spinal curve malformations) when compared with $\mathrm{mAb}$ control-exposed embryos and a nonsignificant increase in the percentage of fetuses showing spontaneous movements. 4470 exposure during pregnancy was not associated with changes in general parameters of maternal well-being or fetal development; indeed, male neonates showed faster weight gain and shorter time to reach developmental milestones.

\section{Conclusions}

$\mathrm{FcRn}$ blockade is a promising therapeutic strategy to prevent the occurrence of AMC and other human maternal autoantibody-related diseases in the offspring.

\author{
Correspondence \\ Dr. Vincent \\ angela.vincent@ndcn.ox.ac.uk
}




\section{Glossary}

$\mathrm{AChR}=$ acetylcholine receptor; $\mathrm{AMC}=$ arthrogryposis multiplex congenita; $\mathrm{ANOVA}=$ analysis of variance; $\mathrm{fAChR}=$ fetal form of the AChR; FcRn = neonatal Fc receptor; IgG = immunoglobulin G; IP = intraperitoneal; $\mathbf{m A b}=$ monoclonal antibody; MG = myasthenia gravis.

Immunoglobulin $\mathrm{G}(\mathrm{IgG})$ antibodies are transferred via the placenta from mother to fetus. This process, mediated by the neonatal $\mathrm{Fc}$ receptor $(\mathrm{FcRn})$, protects the neonate against infectious agents. Transfer of maternal disease-associated IgG antibodies or those pathogenic to the fetus, however, can cause disease in the offspring (see reference 1 for a review). One of the best examples of these phenomena is maternal myasthenia gravis (MG) in which transfer of acetylcholine receptor (AChR) antibodies may be associated with neonatal MG. Moreover, transfer of maternal antibodies that specifically inhibit the fetal form of the AChR (fAChR), although rare, can cause lack of fetal movement in utero, resulting in arthrogryposis multiplex congenita (AMC). ${ }^{2}$ This can lead to fetal or neonatal death, as demonstrated by injecting maternal plasma or purified IgG containing fAChR antibodies into pregnant mouse dams. ${ }^{3}$

Although the symptoms of typical transient neonatal MG usually improve spontaneously, AMC and a recently described persisting myopathy in surviving children ${ }^{4-7}$ likely require treatment during development. Moreover, there is growing evidence that pathogenic maternal antibodies to neuronal antigens could cause long-lasting neurodevelopmental disorders. ${ }^{7-10}$

In addition to regulating transplacental transfer of IgG during pregnancy, $\mathrm{FcRn}$ also rescues $\mathrm{IgG}$ from intracellular degradation and is responsible for the long half-life of $\operatorname{IgG}$ (and pathogenic IgG autoantibodies) relative to other plasma proteins. ${ }^{11}$ Monoclonal antibodies that inhibit FcRn, such as rozanolixizumab, have been developed to treat IgG autoantibodymediated diseases. ${ }^{12,13}$ However, there are no in vivo studies describing the use of these FcRn-inhibiting antibodies to prevent maternal-to-fetal transfer of pathogenic antibodies. Rozanolixizumab does not bind to rodent $\mathrm{FcRn}$, but a surrogate monoclonal antibody (mAb), called 4470, has been produced and previously shown efficacy in mouse models of autoimmune disease. $^{14,15}$

We used our previously established AMC mouse maternal-tofetal transfer model ${ }^{3}$ to see whether inhibiting FcRn during gestation with 4470 reduces pathogenic IgG transfer in utero and decreases the likelihood of disease in the offspring.

\section{Methods}

\section{Experimental Design}

An overview of the experimental design ${ }^{3}$ is depicted in figure 1A. Briefly, Hsd:ICR (CD-1) outbred mice were purchased from a licensed breeding establishment
(Envigo, Indianapolis, IN), mated in house, with pregnancy established by detection of vaginal coagulant plugs (defining day E0.5). Preparations of AChR-positive IgG were injected daily, via the intraperitoneal (IP) route between E12.5 and 17.5 (or E18.5 if dams were allowed to deliver). The treatment group further received 4470 (UCB Pharma, Brussels, Belgium, lot \# PB2226) at doses between 0 and $40 \mathrm{mg} / \mathrm{kg}$, administered via IP injection at E12.5 and E15.5. Control animals received a mouse IgG1 isotype $\mathrm{mAb}$ control (101.4; UCB Pharma, lot \# PB3038). At E18.5, the dams were killed by $\mathrm{CO}_{2}$ anesthesia, followed by cardiac puncture for blood collection. After dissection of the fetuses, each conceptus was weighed and crownrump length measured. The presence of resorptions, embryonic lethalties, deformities and spontaneous movements were recorded. Fetuses were bled by decapitation. Human IgG and AChR Abs were measured in the dams and pooled fetal sera using a human IgG ELISA kit (Cambridge Bioscience, United Kingdom) and radioimmunoassay (RSR Ltd., Pontprennau, United Kingdom), respectively. For the study of neonatal behavioral outcomes, dams were allowed to deliver, and litters were randomly culled to 5-6 pups at postnatal day 1 . Their physical and neurodevelopmental outcomes were assessed using the modified Fox battery, as previously reported. ${ }^{10}$ Details of methods are given in the e-Methods (links.lww.com/NXI/A493).

\section{Human Material}

Plasma exchange samples from a female patient with AChRpositive myasthenia gravis (AChR-IgG) and 2 mothers whose fetuses had AMC $\left(\mathrm{AMCl}^{2,3}\right.$ and $\left.\mathrm{AMC6}^{3}\right)$ were used. The preparation of human IgGs was as previously described. ${ }^{10}$ The patients, purified IgG concentrations, and number of injected dams for each experiment are summarized in figure 1B. Most experiments were performed with AMC6-IgG, as the AMC1 preparation was very scarce. AMC6 had MG diagnosed after her second affected baby was terminated for lack of fetal movements. This baby at postmortem displayed hydrops, scoliosis, pectus excavation, abnormal genitalia, ascites, myositis, and CNS anomalies. ${ }^{3}$ In our previous work, transfer of AMC1 plasma produced a high proportion of dead or paralyzed pups, whereas $60 \%$ of the offspring of dams injected with AMC6 plasma were normal. ${ }^{3}$ Hence, in the mouse model, AMC6 plasma is not as pathogenic as $\mathrm{AMC1}$ plasma.

Titrations of the patients' plasmas against human AChR are shown in figure $1 \mathrm{C}$. The MG AChR Ab plasma precipitated maximum $\alpha$-bungarotoxin-AChR counts per minute at $1 \mu \mathrm{L}$, 


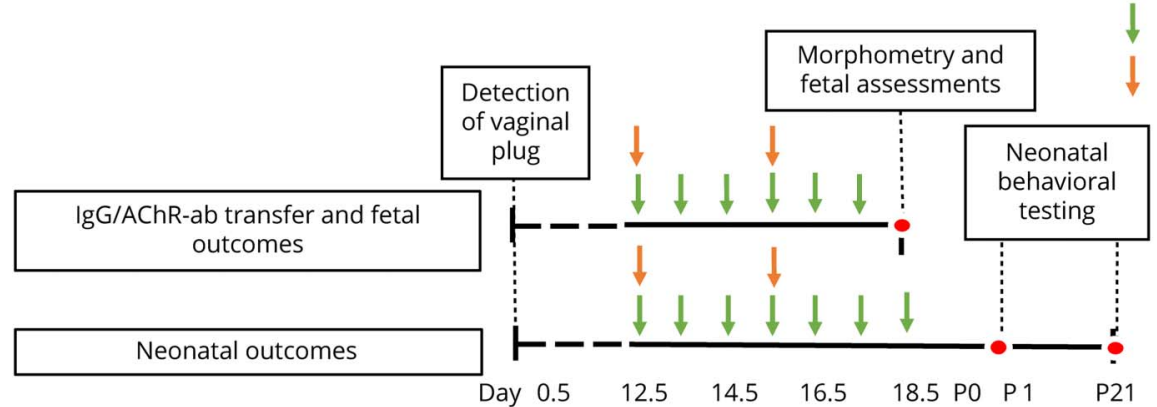

$$
\begin{aligned}
& \text { IgG/sera ip injection } \\
& 4470 / \text { control mAb ip injection }
\end{aligned}
$$

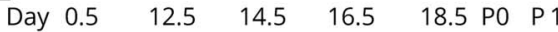

B

\begin{tabular}{|c|c|c|c|c|}
\hline & Clinical information & $\begin{array}{c}\text { IgG } \\
\text { injected ip }\end{array}$ & $\begin{array}{c}\text { Number of } \\
\text { injected } \\
\text { dams }\end{array}$ & Experiments \\
\hline $\begin{array}{c}\text { AChR- } \\
\text { IgG }\end{array}$ & Patient with Myasthenia Gravis & $7 \mathrm{mg}$ & 12 & $\begin{array}{c}\text { IgG/ AChR-ab } \\
\text { transfer }\end{array}$ \\
\hline $\begin{array}{c}\text { AMC1- } \\
\text { IgG }\end{array}$ & $\begin{array}{c}\text { 7 pregnancies; 6 fetuses/ } \\
\text { neonates with typical features } \\
\text { of AMC. No MG at time of } \\
\text { diagnosis. }\end{array}$ & $7 \mathrm{mg}$ & 2 & Fetal outcomes \\
\hline $\begin{array}{c}\text { AMC6- } \\
\text { IgG }\end{array}$ & $\begin{array}{c}\text { 2 pregnancies; 2 fetuses/ } \\
\text { neonates with typical features } \\
\text { of AMC. MG after second } \\
\text { pregnancy }\end{array}$ & $10-12 \mathrm{mg}$ & 16 & $\begin{array}{c}\text { Fetal and } \\
\text { neonatal } \\
\text { outcomes }\end{array}$ \\
\hline
\end{tabular}

C

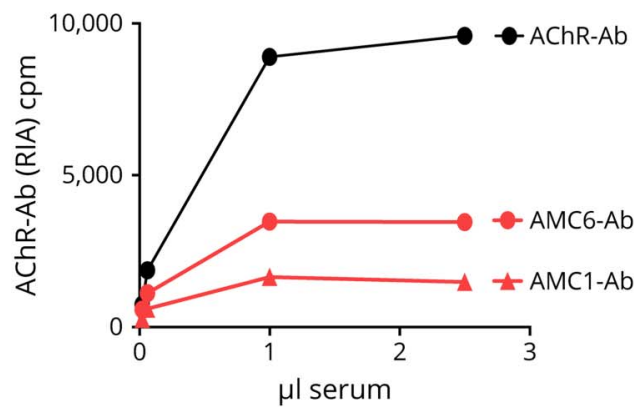

(A) Experimental design: CD-1 dams were injected intraperitoneally (IP) with human purified IgG or plasma containing AChR antibodies from E12.5 to E17.5 or E18.5. Dams in the treatment group were further injected intraperitoneally with 4470, an anti-FcRn monoclonal antibody (mAb) murinized (from UCB Pharma) at doses between 0 and $40 \mathrm{mg} / \mathrm{kg}$ at days E12.5 and 15.5. The control group received a mouse IgG1 isotype mAb control. Dams and offspring were killed at the end of gestation (E18.5) and sera collected for human IgG and AChR antibody testing, or to assess neonatal outcomes, dams were allowed to deliver, and at P1, litters were reduced to 5-6 pups. Neonatal assessments were conducted from P1 to P21. (B) Human material used: patient's clinical history, IgG concentration, and number of injected dams for each experiment. (C) Titration of the patient plasmas against human AChR. Compared with the typical AChR-IgG, the 2 AMCIgG preparations are relatively specific for the fetal isoform (approximately $40 \%$ of the total $10,000 \mathrm{cpm}$ ), but AMC1 serum (and IgG, not shown) displaces one of the ${ }^{125}$-a-bungarotoxins from the fetal AChR explaining the low plateau values shown. AChR = acetylcholine receptor; AMC = arthrogryposis multiplex congenita; cpm = counts per minute; IgG = immunoglobulin $\mathrm{G}$.

but, as in previous studies, ${ }^{2}$ the apparent binding of the 2 AMC plasmas plateaued at much lower counts per minute. This is typical of AMC samples, as the antibodies bind predominantly to the fAChR (approximately $40 \%$ of the human $\mathrm{AChR}$ preparation) and also, to varying extents, particularly $\mathrm{AMC}$, displace the radioactive label from one of the $2 \mathrm{fAChR}$ ${ }^{125}$ I-bungarotoxin/acetylcholine binding sites. ${ }^{2}$ As a result, fAChR antibody titers based on radioimmunoprecipitation assays often appear lower than the typical AChR antibody titers. $^{3}$

\section{Standard Protocol Approvals, Registrations, and Patient Consents}

Serum and plasma samples were archived with the patient's consent and ethical approval for future research from the Central Oxford Research Ethics Committee (COREC 1702, 1988-1993, extended to 1998).

All in vivo experiments, with IgG preparations coded and investigators blinded, adhered to the ARRIVE guidelines and were performed in accordance with the United Kingdom
Animals (Scientific Procedures) Act, 1986, and European Union Directive 2010/63/EU. The experiments were performed under HO license PPL 40/3581 with ethical approval granted by the King's College London Animal Welfare and Ethical Review Body (AWERB).

\section{Statistics}

Results were analyzed by the independent samples $t$ test ( 2 tailed) or by 1-way analysis of variance (ANOVA) with Bonferroni correction for multiple comparisons as appropriate. A statistically significant result was considered if $p<0.05$. Effect sizes are given as Cohen $d$ or eta-squared $\left(\eta^{2}\right)$. Analysis was performed in IBM SPSS statistics v27.0 (SPSS Inc., Chicago, IL). Graphs were plotted using Graph Pad prism v8 (GraphPad software, San Diego, CA). Data are presented as mean \pm SEM, unless otherwise stated.

\section{Data Availability}

All data generated from this study will be shared at the request of other investigators for purposes of replicating procedures and results. 


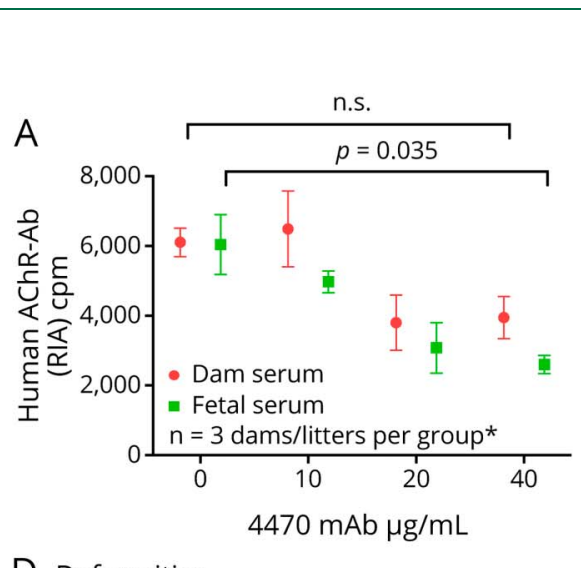

D. Deformities
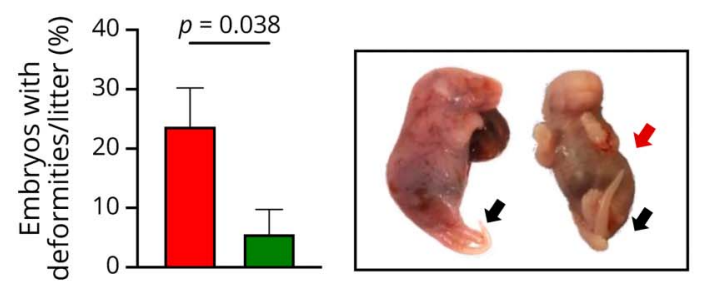

B

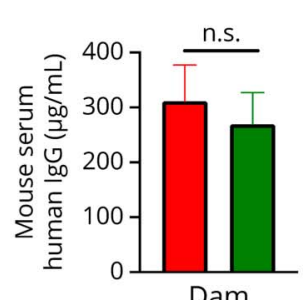

Dam

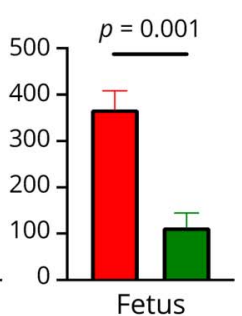

Fetus
C

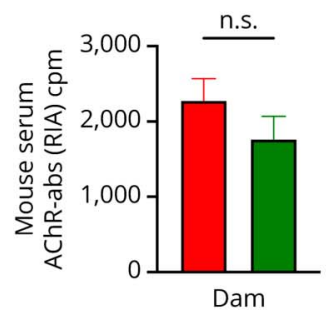

$(\mathrm{n}=6$ dams/litters)

AMC-IgG + $4470 \mathrm{mAb}$

( $\mathrm{n}=6$ dams/litters)

(A) Effect of different concentrations of 4470 on the transfer of typical AChR antibodies measured by radioimmunoassay, showing reduction of transfer to the fetal sera at $40 \mathrm{mg} / \mathrm{kg}$ (dam serum, red; fetal sera, green). *1 dam/litter pair excluded in the 20 and $40 \mathrm{mg} / \mathrm{kg}$ groups due to blood contamination. (B and C) Effect of 4470 (green) vs mAb control (red) at $40 \mathrm{mg} / \mathrm{kg}$ on the levels of total human IgG (B) and AChR antibodies (C). (D) Effect of 4470 (green) vs mAb control (red) at $40 \mathrm{mg} / \mathrm{kg}$ on the presence of deformities; representative microphotograph showing deformities in the limbs (black arrow) and spinal curve (red). (E) Effect of 4470 (green) vs mAb control (red) at $40 \mathrm{mg} / \mathrm{kg}$ on the presence of spontaneous movement. (F) Effect of 4470 (green) vs mAb control (red) at $40 \mathrm{mg} / \mathrm{kg}$ on the presence of empty placentas and embryos undergoing resorption. $\mathrm{AChR}=$ acetylcholine receptor; $\mathrm{AMC}=$ arthrogryposis multiplex congenita; cpm = counts per minute; FcRn = neonatal Fc receptor; IgG = immunoglobulin G; mAb = monoclonal antibody.

\section{Results}

\section{Effect of FcRn Blockade on the Transfer of Human AChR Antibodies and Total IgG}

The effect of different concentrations of $4470(0,10,20$, and $40 \mathrm{mg} / \mathrm{kg}$ ) on the transfer of AChR antibodies from a patient with typical MG (binding largely to the 2 alpha subunits common to both adult and fAChRs) was tested first (figure $2 \mathrm{~A})$. The drug had only a suggestive effect on the antibody titers in the dams (ANOVA; $p=0.06 ; \eta^{2}=0.67$ ), but reduced the antibody titer in their fetuses (ANOVA; $p=0.02 ; \eta^{2}=$ $0.78)$, significant at $40 \mathrm{mg} / \mathrm{kg}$ after Bonferroni correction (0 vs $40 \mathrm{mg} / \mathrm{kg}$; adjusted $p=0.035$ ). Importantly, FcRn blockade was not associated with changes in the embryo's survival, weight, or crown-rump length or in the dams' gestational weight gain at the doses tested (figure e-1, links.lww.com/ NXI/A493). Forty milligrams per kilogram was chosen for the main experiments.

We then tested the effects of 4470 on the transfer of human total IgG and AChR Abs using IgG preparations purified from the 2 AMC plasmas. Twelve dams were injected daily with AMC1-IgG (2 dams) or AMC6-IgG (10 dams) from E12.5 to E17.5; half were injected with $4470(40 \mathrm{mg} / \mathrm{kg})$ on days 12.5 and 15.5, whereas the other half received the isotype $\mathrm{mAb}$ control antibody. There was no reduction in IgG levels in the 4470-treated dams compared with mAb control-injected dams ( $p=0.64$, unpaired $t$ test [ 2 tailed]; Cohen $d=0.28$ ) but a clear reduction $(\sim 60 \%$; $p=0.001$, unpaired $t$ test [ 2 tailed]; Cohen $d=2.94$ ) in their fetuses (figure $2 \mathrm{~B}$ ). The AChR Ab levels followed the same pattern with substantial reduction in the fetuses ( $~ 67 \%$; $p=0.04$, unpaired $t$ test [2 tailed]; Cohen $d=1.7)$, exposed to 4470 , but not in the dams $(p=0.27$, unpaired $t$ test [ 2 tailed]; Cohen $d=0.8$ ) (figure 2C).

\section{Effects of FcRn Blockade on Fetal Outcomes}

Fifty-three 4470-treated embryos and $79 \mathrm{mAb}$ controltreated embryos (from 6 litters per treatment group) were studied at E18.5. To control for the differences in the numbers of embryos in the different litters, data are presented as percentage of affected embryos per litter. Treatment with 4470 was associated with a significant reduction in the percentage of embryos per litter with AMC-IgG-induced deformities when compared with $\mathrm{mAb}$ control-exposed litters $(p=0.038$, independent samples $t$ test [ 2 tailed]; Cohen $d=1.38$ ). In general, the deformities observed consisted of limb or spinal curve malformations rather than embryonic lethality, which likely reflects the use of the less pathogenic patient sample (AMC6; figure 2D). Treatment with 4470 was also associated with a numerical increase in the percentage of embryos showing spontaneous movements (mainly an inspiratory breathing gasp after dissection of the embryos from the uteri) after AMC-IgG exposure, but this failed to reach statistical significance $(p=0.085$, unpaired $t$ test [ 2 tailed], Cohen $d=$ 
A. Males: treatment group ${ }^{\star T}$ Time: $p<0.0001$

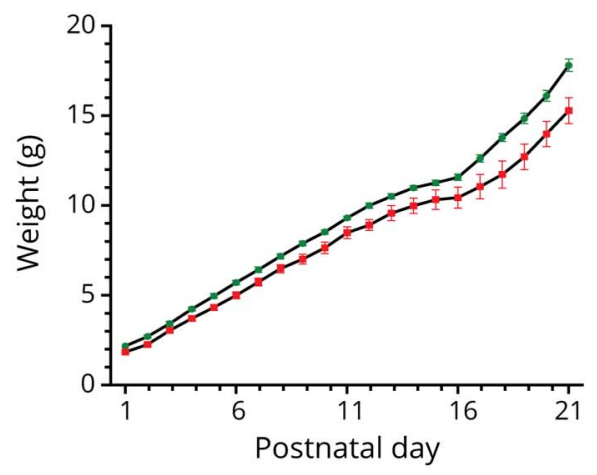

B. Females: treatment group*Time: n.s.

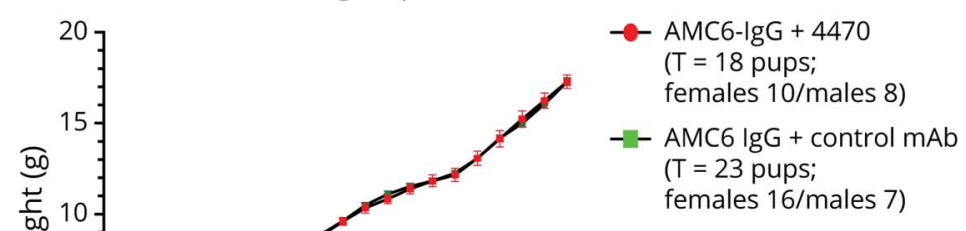

C. Ear twitching

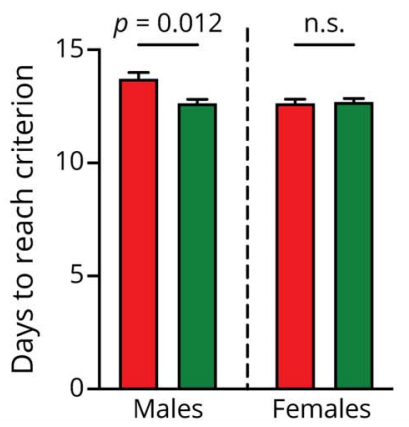

D. Eye opening

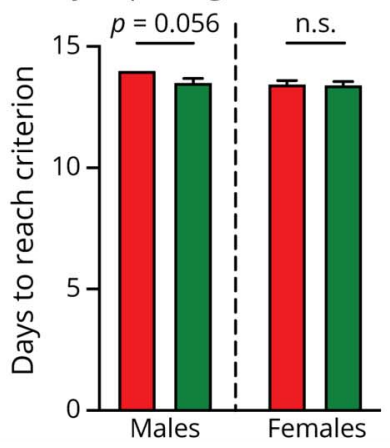

E. Negative geotaxis

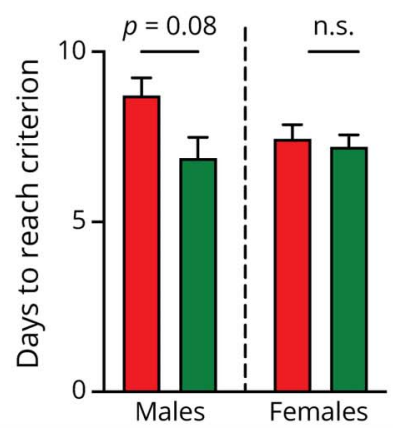

F. Open field

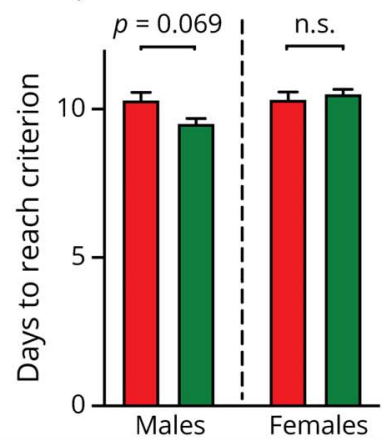

(A) Male and (B) female pups' neonatal weight increase from P1 to P21. Days to reach criterion on ear twitching (C), eye opening (D), negative geotaxis (E), and open field (F) testing. AMC = arthrogryposis multiplex congenita; FcRn = neonatal Fc receptor; IgG = immunoglobulin G.

1.1; figure 2E). One 4470/AMC6-IgG-treated dam had an unusual number of empty placentas and embryos undergoing resorptions, but among all other dams, the embryos appeared normal in number, and the percentage of resorptions per litter did not statistically differ between treatment groups $(p=0.15$ unpaired $t$ test [ 2 tailed]; Cohen $d=0.9$; figure $2 \mathrm{~F}$ ).

\section{Effect of FcRn Blockade on Neonatal Behavior}

Recently, it has become clear that surviving children of mothers whose earlier pregnancies have been still-born or died neonatally may have facial myopathies and other defects. ${ }^{5}$ Accordingly, we examined surviving pups exposed to AMC-IgG during the neonatal period for evidence of neuromotor or other developmental dysfunction. Four dams per treatment arm were injected daily with AMC6-IgG from E12.5 to E18.5 and allowed to deliver. Unfortunately, one of the dams from the 4470-treatment group did not complete gestation (due to a technical error). Among the surviving pups (thirty-four 4470 treated and $43 \mathrm{mAb}$ control treated; $p=0.5$, unpaired $t$ test [ 2 tailed]), 5-6 pups per litter were randomly selected for further testing (eighteen 4470 treated and $24 \mathrm{mAb}$ control treated).

There were no clear differences between 4470 and mAb control mice in terms of weight gain over the first 21 days or in results of the FOX battery for neonatal development (figure e-2, links.lww.com/NXI/A493). However, in a post hoc analysis of the pups by sex, an unexpected sex difference emerged. Those male pups who were not treated with 4470 did significantly worse in terms of weight gain during the neonatal period (males: time $\times$ group $p<0.0001$; females: time $\times$ group $p=0.99$, repeated measures ANOVA) compared with the mAb controls, and the weight difference became more marked over time, suggesting difficulties in suckling or feeding (figure 3, A and B). The mAb controltreated males also took longer to reach criterion, statistically significant in parameters related to tasks involving cranial or limb muscles, and showing strong trends in parameters such as ear twitch (adjusted $p=0.012$, ANOVA with Bonferroni correction), eye opening (adjusted $p=0.056$ ), negative geotaxis (adjusted $p=0.08$, ANOVA with Bonferroni correction), and open field activity (adjusted $p=0.069$, ANOVA with Bonferroni correction) (figure 3, C, D, and F).

\section{Discussion}

We tested the effects of an FcRn-blocking mAb as a potential therapy in maternal antibody-mediated diseases. Using a mouse model for AMC, treatment with 4470 was associated with a significant reduction of both total human IgG and specific AChR antibodies reaching the fetal circulation. This 
was associated with a reduction in the number of deformities seen in the fetuses and a trend toward an increase in spontaneous movements; moreover, surviving male offspring had better neonatal weight gain and milestones. Overall, these results demonstrate that it should be possible to inhibit IgG placental transfer to protect human babies from effects of pathogenic antibodies.

The transcytosis of maternal IgG across the human placenta and the mouse yolk sac is mediated by the FcRn. ${ }^{16}$ Besides its role in placental transport, the endothelial-expressed FcRn also protects IgG from catabolism, prolonging its half-life. ${ }^{17}$ Due to its role in IgG recycling, there has been a surge of interest in FcRn-targeting therapeutics for the treatment of autoimmune diseases. ${ }^{13}$ One recent study has investigated the use of a similar $\mathrm{mAb}$ on the placenta. An FcRn high-affinity mAb (M281) decreased IgG transfer in a human ex vivo placental perfusion model. ${ }^{18}$ Our study uses an in vivo system of a well-established model of maternal-to-fetal transfer of pathogenic antibodies, with excellent construct, face and predictive validity for an antibody-mediated neonatal disease.

We used a murine surrogate of rozanolixizumab, 4470, a highly specific mAb that binds to the IgG binding site on FcRn with high affinity in a $\mathrm{pH}$-independent way, preventing the recycling and transcytosis of IgG. ${ }^{19}$ Importantly, 4470 does not impact on the capacity of FcRn to bind to albumin (another FcRn neurodevelopment-relevant ligand). Also of relevance, rozanolixizumab has been used in adult patients and has been found to be well tolerated with an acceptable safety profile. ${ }^{20,21}$

Important questions, however, require further research. First, the timing of IgG transfer differs in humans and rodents; in the latter, it occurs mainly during lactation. By contrast, in humans, maternal IgG is transferred from around gestational week 14, but the fAChR is replaced by the adult from around week 30 , so treatment could be restricted to midgestation. Second, our study was not powered to take into consideration sex differences in neonatal outcome, but our results suggest that untreated male pups might do worse if exposed to pathogenic fAChR antibodies. The reason for this difference is not known, and at present, there are few data on the sex of surviving babies born to mothers with these antibodies. Third, the results from the model are greatly influenced by the AMC serum used, as is often the case in animal models for antibody-mediated disease. Unfortunately, the most abundant AMC sample, and thus the one used for the majority of experiments (AMC6), was previously found to be less pathogenic in animals, ${ }^{3}$ and it is therefore possible that our results are understated. A further concern relates to the risk of transient hypogammaglobulinemia of the newborn and associated risk of infections (since neonatal IgG production only starts at 6 months of age). This could apply if the FcRn blockade was required in the last trimester to prevent neonatal disease rather than midgestation. If hypogammaglobulinemia was detected in the newborn, passive immunoglobulin could be administered at birth, as is current practice in similar clinical situations. Finally, although not a statistically significant difference, the number of resorptions was higher in the treatment group. This observation was driven by a single animal who had a high number of embryos undergoing resorptions and we did not observe a difference on embryos' survival when testing different dosages of the drug. However, this will need careful assessment in future studies.

Despite these limitations and open questions, our study supports further research into FcRn blockade as a promising therapeutic strategy to prevent disease before irreversible damage to the fetus/newborn is established. In particular, this study could have wide implications in the prevention of other maternal antibody-mediated diseases, ${ }^{22}$ neonatal lupus syndrome, ${ }^{23}$ or even forms of autism and intellectual disability with the growing evidence for pathogenic maternal antibodies to CNS antigens. ${ }^{7-10,24}$

\section{Acknowledgment}

A. Vincent thanks Prof. David Beeson for his support.

\section{Study Funding}

This study was partially funded by UCB Pharma and an MRC Centre grant (MR/N026063/1). E. Coutinho is supported by a clinical fellowship from the MRC Centre for Neurodevelopmental disorders.

\section{Disclosure}

E. Coutinho and L. Jacobson report no disclosures. A. Shock is an employee of UCB Pharma and holds stock options. B. Smith is a former employee of UCB Pharma; UCB Pharma is the manufacturer and sponsor of rozanolixizumab, an FcRn inhibitor, which is currently being investigated in clinical trials in a number of autoimmune disorders. A. Vernon reports no disclosures. A. Vincent and the University of Oxford hold patents for MuSK, LGI1, CASPR2 and VGKC-complex antibody assays, licensed to Athena Diagnostics and Euroimmun AG, not relevant to this study. Go to Neurology.org/NN for full disclosures.

\section{Publication History}

Received by Neurology: Neuroimmunology \& Neuroinflammation January 24, 2021. Accepted in final form March 17, 2021.

Appendix Authors

\begin{tabular}{lll}
\hline Name & Location & Contribution \\
\hline $\begin{array}{l}\text { Ester } \\
\text { Coutinho, } \\
\text { MD, DPhil }\end{array}$ & $\begin{array}{l}\text { Department of Basic and } \\
\text { Clinical Neuroscience, } \\
\text { Institute of Psychiatry, } \\
\text { Psychology and }\end{array}$ & $\begin{array}{l}\text { Drafting/revision of the } \\
\text { manuscript for content, } \\
\text { including medical writing for } \\
\text { couroscience, Maurice Wohl } \\
\text { Clinical Neuroscience } \\
\text { Institute; Medical Research } \\
\text { acquisition of data; study } \\
\text { concept or design; and } \\
\text { analysis or interpretation of } \\
\text { data }\end{array}$ \\
& $\begin{array}{l}\text { Neurodevelopmental } \\
\text { Disorders, King's College } \\
\text { London, United Kingdom }\end{array}$ & \\
&
\end{tabular}


Appendix (continued)

\begin{tabular}{lll}
\hline Name & Location & Contribution \\
\hline $\begin{array}{l}\text { Leslie } \\
\text { Jacobson, } \\
\text { DPhil }\end{array}$ & $\begin{array}{l}\text { Nuffield Department of } \\
\text { Clinical Neurosciences, } \\
\text { University of Oxford, United } \\
\text { Kingdom }\end{array}$ & $\begin{array}{l}\text { Major role in the acquisition } \\
\text { of data; study concept or } \\
\text { design; and analysis or } \\
\text { interpretation of data }\end{array}$ \\
\hline $\begin{array}{l}\text { Anthony } \\
\text { Shock, PhD }\end{array}$ & $\begin{array}{l}\text { UCB Pharma, Slough, United } \\
\text { Kingdom }\end{array}$ & $\begin{array}{l}\text { Drafting/revision of the } \\
\text { manuscript for content, } \\
\text { including medical writing for } \\
\text { content; study concept or } \\
\text { design; and analysis or } \\
\text { interpretation of data. } \\
\text { Additional contributions: } \\
\text { provision of FcRn and control } \\
\text { monoclonal antibodies }\end{array}$ \\
\end{tabular}

\begin{tabular}{lll}
\hline Bryan & UCB Pharma, Slough, United & Drafting/revision of the \\
Smith, PhD Kingdom & manuscript for content, \\
& including medical writing for \\
& content; study concept or \\
& design; and analysis or \\
& interpretation of data. \\
& Additional contributions: \\
& provision of FcRn and control \\
& monoclonal antibodies
\end{tabular}

\begin{tabular}{|c|c|c|}
\hline $\begin{array}{l}\text { Anthony } \\
\text { Vernon, } \\
\text { PhD }\end{array}$ & $\begin{array}{l}\text { Department of Basic and } \\
\text { Clinical Neuroscience, } \\
\text { Institute of Psychiatry, } \\
\text { Psychology and } \\
\text { Neuroscience, Maurice Wohl } \\
\text { Clinical Neuroscience } \\
\text { Institute; Medical Research } \\
\text { Council Centre for } \\
\text { Neurodevelopmental } \\
\text { Disorders, King's College } \\
\text { London, United Kingdom }\end{array}$ & $\begin{array}{l}\text { Drafting/revision of the } \\
\text { manuscript for content, } \\
\text { including medical writing for } \\
\text { content; major role in the } \\
\text { acquisition of data; study } \\
\text { concept or design; and } \\
\text { analysis or interpretation of } \\
\text { data }\end{array}$ \\
\hline $\begin{array}{l}\text { Angela } \\
\text { Vincent, } \\
\text { MD, } \\
\text { FRCPath }\end{array}$ & $\begin{array}{l}\text { Nuffield Department of } \\
\text { Clinical Neurosciences, } \\
\text { University of Oxford, United } \\
\text { Kingdom }\end{array}$ & $\begin{array}{l}\text { Drafting/revision of the } \\
\text { manuscript for content, } \\
\text { including medical writing for } \\
\text { content; major role in the } \\
\text { acquisition of data; study } \\
\text { concept or design; and analysis } \\
\text { or interpretation of data }\end{array}$ \\
\hline
\end{tabular}

\section{References}

1. Chang C. Neonatal autoimmune diseases: a critical review. J Autoimmun. 2012;38: J223-J238.

2. Riemersma S, Vincent A, Beeson D, et al. Association of arthrogryposis multiplex congenita with maternal antibodies inhibiting fetal acetylcholine receptor function. J Clin Invest. 1996;98:2358-2363.
3. Jacobson L, Polizzi A, Morriss-Kay G, Vincent A. Plasma from human mothers of fetuses with severe arthrogryposis multiplex congenita causes deformities in mice. J Clin Invest. 1999; 103:1031-1038.

4. Oskoui M, Jacobson L, Chung WK, et al. Fetal acetylcholine receptor inactivation syndrome and maternal myasthenia gravis. Neurology. 2008;71:2010-2012.

5. Hacohen Y, Jacobson LW, Byrne S, et al. Fetal acetylcholine receptor inactivation syndrome: a myopathy due to maternal antibodies. Neurol Neuroimmunol Neuroinflamm. 2015;2:e57.

6. Reimann J, Jacobson L, Vincent A, Kornblum C. Endplate destruction due to maternal antibodies in arthrogryposis multiplex congenita. Neurology. 2009;73: 1806-1808.

7. Garcia-Serra A, Radosevic M, Pupak A, et al. Placental transfer of NMDAR antibodies causes reversible alterations in mice. Neurol Neuroimmunol Neuroinflamm. 2021;8:e915.

8. Brimberg L, Mader S, Jeganathan V, et al. Caspr2-reactive antibody cloned from a mother of an ASD child mediates an ASD-like phenotype in mice. Mol Psychiatry. 2016;21:1663-1671.

9. Jurek B, Chayka M, Kreye J, et al. Human gestational N-methyl-d-aspartate receptor autoantibodies impair neonatal murine brain function. Ann Neurol. 2019;86: 656-670.

10. Coutinho E, Menassa DA, Jacobson L, et al. Persistent microglial activation and synaptic loss with behavioral abnormalities in mouse offspring exposed to CASPR2antibodies in utero. Acta Neuropathol. 2017;134:567-583.

11. Pyzik M, Sand KMK, Hubbard JJ, Andersen JT, Sandlie I, Blumberg RS. The neonatal Fc receptor (FcRn): a misnomer? Front Immunol. 2019;10:1540.

12. Patel DD, Bussel JB. Neonatal Fc receptor in human immunity: function and role in therapeutic intervention. J Allergy Clin Immunol. 2020;146:467-478.

13. Zuercher AW, Spirig R, Baz Morelli A, Rowe T, Kasermann F. Next-generation Fc receptor-targeting biologics for autoimmune diseases. Autoimmun Rev. 2019;18:102366.

14. Smith B, Christodoulou L, Clargo A, et al. Generation of two high affinity anti-mouse $\mathrm{FcRn}$ antibodies: inhibition of IgG recycling in wild type mice and effect in a mouse model of immune thrombocytopenia. Int Immunopharmacol. 2019;66:362-365.

15. Kasprick A, Hofrichter M, Smith B, et al. Treatment with anti-neonatal Fc receptor $(\mathrm{FcRn})$ antibody ameliorates experimental epidermolysis bullosa acquisita in mice. $\mathrm{Br}$ J Pharmacol. 2020;177:2381-2392.

16. Roopenian DC, Akilesh S. FcRn: the neonatal Fc receptor comes of age. Nat Rev Immunol. 2007;7:715-725.

17. Lencer WI, Blumberg RS. A passionate kiss, then run: exocytosis and recycling of IgG by FcRn. Trends Cell Biol. 2005;15:5-9.

18. Roy S, Nanovskaya T, Patrikeeva S, et al. M281, an anti-FcRn antibody, inhibits IgG transfer in a human ex vivo placental perfusion model. Am J Obstet Gynecol. 2019;220: 498.e1-498.e9.

19. Smith B, Kiessling A, Lledo-Garcia R, et al. Generation and characterization of a high affinity anti-human $\mathrm{FcRn}$ antibody, rozanolixizumab, and the effects of different molecular formats on the reduction of plasma IgG concentration. MAbs. 2018;10: 1111-1130.

20. Brill V, Benatar M, Henning A, et al. Efficacy and safety of rozanolixizumab in moderate-to-severe generalised myasthenia gravis: a phase 2 RCT. Neurology. 2021; 96:e853-e865. doi: 10.1212/WNL.0000000000011108.

21. Robak T, Kazmierczak M, Jarque I, et al. Phase 2 multiple-dose study of an FcRn inhibitor, rozanolixizumab, in patients with primary immune thrombocytopenia. Blood Adv. 2020;4:4136-4146.

22. Ciobanu AM, Dumitru AE, Gica N, Botezatu R, Peltecu G, Panaitescu AM. Benefits and risks of IgG transplacental transfer. Diagnostics (Basel). 2020;10(8):583. doi: 10. 3390/diagnostics 10080583

23. Izmirly P, Saxena A, Buyon JP. Progress in the pathogenesis and treatment of cardiac manifestations of neonatal lupus. Curr Opin Rheumatol. 2017;29(5):467-472. doi: 10. 1097/BOR.0000000000000414.

24. Marks K, Vincent A, Coutinho E. Maternal-autoantibody-related (MAR) autism: identifying neuronal antigens and approaching prospects for intervention. J Clin Med. 2020;9:2564. 


\title{
Neurology \\ Neuroimmunology \& Neuroinflammation
}

\author{
Inhibition of Maternal-to-Fetal Transfer of IgG Antibodies by FcRn Blockade in a \\ Mouse Model of Arthrogryposis Multiplex Congenita \\ Ester Coutinho, Leslie Jacobson, Anthony Shock, et al. \\ Neurol Neuroimmunol Neuroinflamm 2021;8; \\ DOI 10.1212/NXI.0000000000001011
}

This information is current as of May 27, 2021

Updated Information \&
Services
References
Citations
Subspecialty Collections

Subspecialty Collections

Permissions \& Licensing

Reprints including high resolution figures, can be found at:

http://nn.neurology.org/content/8/4/e1011.full.html

This article cites 24 articles, 0 of which you can access for free at: http://nn.neurology.org/content/8/4/e1011.full.html\#\#ref-list-1

This article has been cited by 2 HighWire-hosted articles:

http://nn.neurology.org/content/8/4/e1011.full.html\#\#otherarticles

This article, along with others on similar topics, appears in the following collection(s):

Autoimmune diseases

http://nn.neurology.org//cgi/collection/autoimmune_diseases

Developmental disorders

http://nn.neurology.org//cgi/collection/developmental_disorders

Myasthenia

http://nn.neurology.org//cgi/collection/myasthenia

Information about reproducing this article in parts (figures,tables) or in its entirety can be found online at:

http://nn.neurology.org/misc/about.xhtml\#permissions

Information about ordering reprints can be found online:

http://nn.neurology.org/misc/addir.xhtml\#reprintsus

Neurol Neuroimmunol Neuroinflamm is an official journal of the American Academy of Neurology.

Published since April 2014, it is an open-access, online-only, continuous publication journal. Copyright

Copyright $\odot 2021$ The Author(s). Published by Wolters Kluwer Health, Inc. on behalf of the American

Academy of Neurology.. All rights reserved. Online ISSN: 2332-7812.

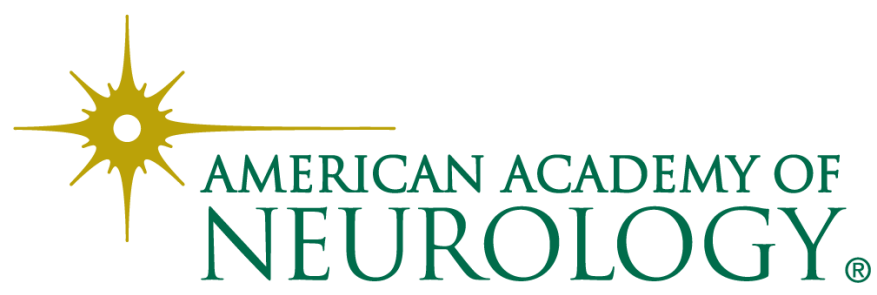

